\title{
Effect of organic enrichments on hydrolytic potentials and growth of bacteria in deep-sea sediments
}

\author{
A. Boetius ${ }^{1, *}, \mathrm{~K}$. Lochte $^{2}$ \\ 'Alfred Wegener Institute for Polar and Marine Research, D-27515 Bremerhaven, Germany \\ ${ }^{2}$ Institute for Baltic Sea Research, D-18112 Warnemünde, Germany
}

\begin{abstract}
To test the response of a natural benthic microbial assemblage to differences in the composition of organic matter supply, surface sediments from the Arctic continental slope (1000 m water depth) were enriched with a variety of organic compounds. Glycine and glucose represent substrates which can be directly utilized by bacteria; protein, chitin, cellulose, starch and the lipid Tween require extracellular hydrolysis by peptidase, chitobiase, $\beta$-glucosidase, $\alpha$-glucosidase and lipase, respectively. The effect of these enrichments on hydrolytic activity potentials and on several parameters of microbial biomass was observed over a period of $63 \mathrm{~d}$. Within $10 \mathrm{~d}$, specific activities of $\beta$-glucosidase and chitobiase were enhanced by their respective substrates by a factor of 10 to $20 . \alpha$-Glucosidase and peptidase were greatly inhibited in the presence of glucose and glycine, respectively. Peptidase, $\alpha$-glucosidase and lipase activities were not induced by their respective substrates. The supply of starch, lipid and cellulose did not cause detectable growth of the bacterial assemblage for the whole period of the experiment. Enrichment with glycine, albumin, chitin and glucose resulted in significant biomass production of the bacterial populations with simular growth rates of $0.1 \mathrm{~d}^{-1}$ after a lag phase of up to $10 \mathrm{~d}$. However, the supply of amino acid sources resulted in a $60 \%$ higher bacterial biomass yield after $63 \mathrm{~d}$ compared to chitin and glucose.
\end{abstract}

KEY WORDS: Extracellular enzymes Bacterial growth - Benthic bacteria - Organic matter supply Deep-sea sediments

\section{INTRODUCTION}

Most of the organic matter (OM) sinking to the deepsea floor is utilized by benthic organisms and only a small fraction is finally preserved in the sedimentary record due to its refractory composition or due to molecular adsorption (Hedges \& Keil 1995). An understanding of the factors controlling OM degradation and preservation is central to modelling biogeochemical cycles in marine sediments. In the deep sea, the processes of OM degradation are dominated by bacteria (Rowe et al. 1991). However, estimates of bacterial production as well as remineralization rates in bathyal and abyssal sediments vary over 3 orders of magni-

- Present address: Institut für Ostseeforschung, Seestr. 15 , D-18119 Rostock-Warnemünde, Germany.

E-mail: antje.boetius@io-warnemuende.de tude, closely related to differences in OM supply, measured as particulate organic carbon fluxes to the sea floor (Jahnke \& Jackson 1992, Deming \& Baross 1993). Furthermore, substrate composition may have a substantial effect on bacterial remineralization and assimilation rates: Turley \& Lochte (1990) supplied natural deep-sea assemblages with phytodetritus and observed a marked decrease in bacterial carbon (C) conversion efficiencies with increasing age of the substrate. Microbial degradation rates in marine sediments were found to depend on molecular structures of organic substrates (Arnosti \& Repeta 1994). Kuenen \& Robertson (1993) reported that the cycling of nitrogen (N) compounds is largely influenced by the $\mathrm{C} / \mathrm{N}$ ratio of $\mathrm{OM}$ in sediments.

The first step in the utilization of particulate OM by bacteria is the extracellular hydrolysis of the polymeric compounds, since only products with a molecular 
weight smaller than 600 dalton can pass through the cell pores (Gottschalk 1986). The aim of this experiment was to test the effect of OM composition on the regulation of microbial hydrolytic enzyme activities, and further, on the development of the standing stocks in natural microbial assemblages from deep-sea sediments. This question was approached by enriching freshly sampled sediments with equal quantities of different substrates. Since previous enrichment experiments with bacteria from deep-sea sediments were restricted to 1-3 wk, obtaining little or no increase in bacterial numbers (Deming 1985, Meyeı-Reil \& Köster 1992, Boetius \& Lochte 1994), bacterial enzymatic activity and growth parameters were observed over a 2 mo incubation period, providing new data on the regulation of bacterial enzymes and substrate utilization.

\section{METHODS}

Sediment samples. The experiment was carried out with sediments sampled by multiple corer (Barnett et al. 1984) at station $2447\left(82^{\circ} 09^{\prime} \mathrm{N}, 42^{\circ} 02^{\prime} \mathrm{E}\right)$ northwest of Franz-Joseph-Land (Arctic Circle) at $1013 \mathrm{~m}$ water depth during RV 'Polarstern' cruise ARK IX/4 in August 1993 (Fütterer 1994). The samples were transferred to a cold room immediately after sampling and all sample handling was carried out at the in situ temperature of $-1^{\circ} \mathrm{C}$. The top $5 \mathrm{~cm}$ of the sediment cores was oxic, consisted of silty clays and had a water content of $60 \%$. Sedimentary organic $\mathrm{C}$ concentration was $15.4 \mathrm{mg} \mathrm{C}^{-1}$ dry weight of sediment and organic $\mathrm{N}$ was $2.1 \mathrm{mg} \mathrm{N} \mathrm{g}^{-1}$ dry weight (Stein in press), equivalent to $9.5 \mathrm{mg} \mathrm{C} \mathrm{cm}{ }^{-3}$ and $1.3 \mathrm{mg} \mathrm{N} \mathrm{cm}{ }^{-3}$ wet sediment.

Experimental design. The top $4.5 \mathrm{~cm}$ of bulk sediment from all 1.2 cores of 1 multiple corer was combined in a sterile glass bottle and diluted with 2 parts of sterile filtered $(0.2 \mu \mathrm{m})$ Arctic bottom water. The sediment slurry was thoroughly mixed by shaking the bottle before pouring 8 portions of $500 \mathrm{ml}$ each into sterile $1 \mathrm{l}$ glass bottles. One portion without additional substrate served as control. A first subsample was removed for further analysis of microbial activities and biomass, representative of the conditions on Day 0 . The other portions were enriched with different organic substrates to final concentrations of $1.7 \mathrm{mg}$ glycine, $1.7 \mathrm{mg}$ albumin from egg-white, $3.4 \mathrm{mg}$ glucose, $3.4 \mathrm{mg}$ soluble starch, $3.4 \mathrm{mg}$ microgranular cellulose, $4.4 \mathrm{mg}$ purified chitin flakes from shrimp shells and $13 \mathrm{mg}$ of the water-soluble lipid polyoxyethylensorbitan monolaurate (Tween 20 ) $\mathrm{cm}^{-3}$ undiluted sediment. The additions were equivalent to a substrate input of 0.5 to $2 \mathrm{mg} \mathrm{C} \mathrm{cm}{ }^{-3}$ sediment and 0 to $0.3 \mathrm{mg} \mathrm{N}$ $\mathrm{cm}^{-3}$ sediment. All bottles were incubated in the dark at the in situ temperature of $-1^{\circ} \mathrm{C}$ and atmospheric pressure. The sediments were not stirred except during subsampling on Days 2, 5, 10, 15, 21, 29, 38 and 63. At each of these intervals, a subsample of $60 \mathrm{ml}$ was removed from each bottle after vigorous mixing. Analysis of enzymatic activities and extraction of adenylates followed immediately. For bacterial numbers and biomass determination, $1 \mathrm{ml}$ of the subsample was fixed in $9 \mathrm{ml} 2 \%$ formaldehyde solution and stored at $4^{\circ} \mathrm{C}$ for later analysis in the home laboratory. The rest of the subsample was stored frozen $\left(-20^{\circ} \mathrm{C}\right)$ for the determination of lipid-bound phosphate concentrations in the home laboratory.

Biomass parameters. Subsamples for the determination of bacterial numbers and biomass were prepared according to the method of Velji \& Albright (1986) Bacterial numbers were determined by epifluorescence microscopy (Zeiss Axioskop, Oberkochen, Germany) after staining with acridine orange (Meyer-Reil 1983). Volumetric measurements of the bacterial cells were conducted with the New Porton grid (Graticules Ltd, Tonbridge, UK) as described by Grossmann \& Reichardt (1990). Bacterial biomass was estimated

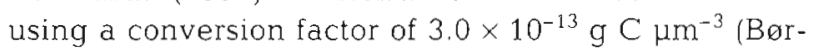
sheim et al. 1990). Each value represents the mean of 30 counted grids obtained from 2 replicate filters.

Adenylates were extracted not later than $10 \mathrm{~h}$ after sampling. Sediments were washed with ice-cold phosphate buffer $(0.2 \mathrm{M}, \mathrm{pH}$ ) ) before extraction of adenylates for $30 \mathrm{~min}$ at $90^{\circ} \mathrm{C}$ with $3 \mathrm{ml}$ glycine buffer (70 mM, pH 9.8) per ml sediment, following Greiser \& Faubel (1988). After centrifugation $(10 \mathrm{~min}, 2800 \times \mathrm{g})$, the supernatant was stored frozen at $-20^{\circ} \mathrm{C}$ until analysis in the home laboratory. The determination of total adenylates (ATP, ADP and AMP) was conducted according to Karl \& Holm-Hansen (1978) by enzymatic conversion of ADP and AMP into ATP. ATP concentrations were quantified using firefly lantern extract (FLE 50, Sigma) during the Luciferin-Luciferase reaction (Karl 1980) with a luminometer (LKB 1250). Each value represents the mean of 5 replicates

Concentrations of phospholipids were determined according to Findlay et al. (1989) with slight modifications as described in Boetius \& Lochte (1994). Each value represents the mean of 5 replicates. Total phospholipid concentrations are generally used to estimate total microbial biomass (White et al. 1979), including bacteria, fungi and protozoa. Concentrations of lipidbound phosphate can be converted into $C$ biomass using the factor of $100 \mu \mathrm{mol} \mathrm{P} \mathrm{g}^{-1} \mathrm{C}$ for natural microbial assemblages including microeucaryotes, and $200 \mu \mathrm{mol} \mathrm{P} \mathrm{g}{ }^{-1} \mathrm{C}$ for bacterial cultures (Dobbs \& Findlay 1993)

To detect a development of distinct microbial communities in the enriched and unenriched treatments, 
fatty acid composition was determined at the end of the experiment in the pooled chloroform extract of total lipids from subsamples of Days 38 and 63 . Individual fatty acids were analysed according to Kattner \& Krause (1987) using a Chrompac 9000 gas chromatograph.

Enzyme activities. The extracellular enzymatic activities (EEA) of the hydrolases $\alpha$-, $\beta$-glucosidase, chitobiase, lipase and aminopeptidase were measured fluorometrically (Hitachi F-2000 spectrofluorometer) according to Boetius \& Lochte (1994), using the methylumbelliferone (MUF) labelled substrates MUF$\alpha$-glucoside (final conc. in the slurries: $50 \mu \mathrm{M}$; Sigma), MUF- $\beta$-glucoside (100 $\mu \mathrm{M}$, Sigma), MUF-N-acetyl- $\beta$ glucosaminide (100 $\mu \mathrm{M}$, Sigma), MUF-stearate $(50 \mu \mathrm{M}$, Sigma) and 4-methylcoumarinyl-7-amide (MCA) labelled leucine (500 $\mu \mathrm{M}$, Serva). Pre-tests were performed with sediment samples from several deep-sea sites to confirm that these final concentrations of MUFor MCA-substrates generally represent substrate saturation levels and yield maximum velocities $\left(V_{\max }\right)$. At the above concentrations, the addition of albumin, cellulose and starch up to $1 \mathrm{mg} \mathrm{cm}^{-3}$ sediment had no effect on the hydrolysis rate of MCA-leucine, MUF- $\beta$ glucoside and MUF- $\alpha$-glucoside, respectively, during a $4 \mathrm{~h}$ incubation (Boetius unpubl., data not shown; for similar tests see Hoppe 1983)

The enzyme assays were run in time course experiments with 3 determinations for 2 to $4 \mathrm{~h}$. The subsamples removed at each time point were centrifuged for 10 min $(2800 \times g)$ at $0^{\circ} \mathrm{C}$. The supernatants were transferred into disposable UV-cuvettes and the fluorescence of MUF and MCA was measured at $365 \mathrm{~nm}$ excitation and $445 \mathrm{~nm}$ emission wavelength. Relative units of fluorescence were calibrated with 5 standard concentrations between 20 and $300 \mathrm{nM}$ of both MUF (Serva) and MCA (Sigma).

Enzyme activity was calculated from the average of the changes in fluorescence during the time course experiment ( 2 to 3 intervals). Each value represents 1 sample and no replicates could be run due to the high number of enzymes and enrichments $(40$ probes) assayed at each time interval.

Calculations and statistics. All data were normalized to the natural water content of the undiluted sediment. Statistical analyses were performed with the statistics program SYSTAT (Wilkinson 1989).

\section{RESULTS}

\section{Effect of substrate enrichment on EEA}

In the incubation of unenriched sediment, which served as control, EEA of $\alpha$-, $\beta$-glucosidase and chito- biase (glycosidases) remained on a constantly low level for $63 \mathrm{~d}$ (Fig. 1a). Of all enzymes, $\alpha$-glucosidase and lipase displayed lowest EEA of around 0.05 to $0.10 \mu \mathrm{M}$ $\mathrm{h}^{-1}$. Lipase dropped below detection limit after $5 \mathrm{~d}$. $\beta$-Glucosidase and chitobiase EEA were around 0.2 to $0.4 \mu \mathrm{M} \mathrm{h}^{-1}$, peptidase EEA was at a much higher level (67 to $144 \mu \mathrm{M} \mathrm{h}^{-1}$ ) than all other enzymes.

\section{Enrichment with monomers}

In the enrichment with glycine (Fig. 1b), EEA of the glycosidases and lipase increased by a factor of 2 to 8 $\left(E_{E A_{d} ;} / E E A_{d 0}\right)$ during the experiment. Peptidase EEA decreased immediately to $10 \mu \mathrm{M} \mathrm{h}^{-1}$ after the addition of glycine, recovering to the level at the beginning of the experiment after $38 \mathrm{~d}$. In the glucose enrichment (Fig. 1c), B-glucosidase was the only enzyme which increased markedly after Day 38. $\alpha$-Glucosidase and peptidase EEA were reduced compared to the control on Days 5 and 21 and Days 5, 21 and 63, respectively.

\section{Enrichment with polymers}

Cellulose enrichment (Fig. 1d) considerably enhanced $\beta$-glucosidase EEA after $10 \mathrm{~d}$ by an order of magnitude. The EEA of both other glycosidases and lipase increased only by a factor of 2 to 3 $\left(E E A_{d i, j} / E E A_{d 0}\right)$ towards the end of the experiment. Peptidase EEA increased at first but was reduced between Days 10 and 21, similar to the enrichment with glucose. The strongest response to chitin enrichment (Fig. 1e) was the increase in chitobiase EEA by more than 1 order of magnitude from Day 10 to Day 38. Between Days 38 and 63, EEA of all other enzymes except peptidase increased substantially, with the latter constantly decreasing throughout the experiment. Enrichment with albumin (Fig 1f) enhanced EEA of all enzymes but peptidase: $\alpha$-glucosidase by a factor of 5 , chitobiase by a factor of $30, \beta$-glucosidase and lipase by a factor of $10\left(E_{E A_{d 63}} / E_{E A_{d 0}}\right)$. Peptidase EEA was lower than in the control at Days 5 and 63. Enriching the sediments with lipid (Fig. 1g) or starch (Fig. 1h) did not result in any distinct changes of EEA compared to the control, indicating that neither $\alpha$-glucosidase nor lipase was substantially affected by addition of their 2 potential substrates over the $63 \mathrm{~d}$.

To track those changes in activity potentials that were not related to variation in microbial biomass, biomass-specific EEA of the hydrolases was calculated. dividing hydrolysis rates by bacterial biomass (for biomass data see Fig. 3). The enhancement in specific activities relative to Day 0 is shown in Fig. $2 \mathrm{a}$ for the control on Day 5 and for all other enrichments on Day 10. 


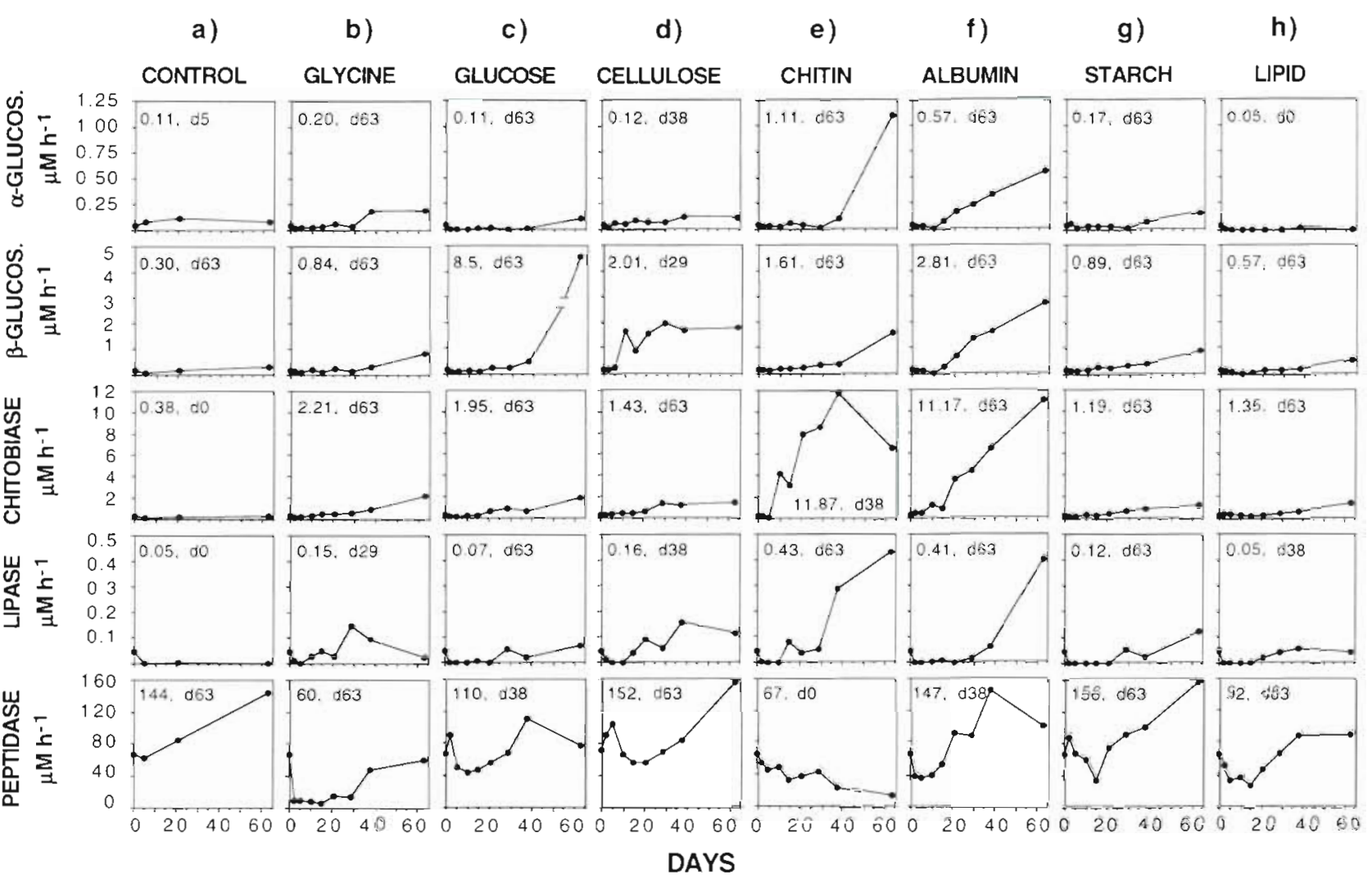

Fig. 1. Extracellular enzymatic activities (EEA). Each graph shows the changes in EEA of 5 enzymes during 63 d of incubation. $\alpha-, \beta$-Glucosidase, chitobiase, lipase and peptidase EEA were measured in (a) unenriched and ( $\mathrm{b}$ to $\mathrm{h}$ ) enriched sediments with 7 different substrates as indicated. Numbers in the left corner of each graph indicate levels ( $\mu \mathrm{M} \mathrm{h}^{-1}$ ) and days of maxımum EEA. Note the different scales of EEA on the $y$-axis for each row

and in Fig 2b for Day 63. On Day 10, bacterial populations were growing in some of the enrichments. Fig. 2a shows that specific EEA potentials were either reduced by the addition of end-products (glucose/ $\alpha$-glucosidase, glycine/peptidase) or enhanced by the addition of substrate (cellulose/ $\beta$-glucosidase, chitin/chitobiase). Furthermore, the addition of albumin reduced specific EEA of $\alpha-, \beta$-glucosidase and lipase. On Day 63 (Fig. 2b) most enzymes were enhanced compared to the beginning of the experiment, except in the control and glycine enrichment, and except for the noticeable decrease in peptidase EEA in the chitin enruchment.

\section{Effect of substrate enrichment on microbial growth}

At the beginning of the experiment, bacterial biomass (BB) was $53.4 \mu \mathrm{g} \mathrm{C} \mathrm{cm}{ }^{-3}\left(22.5 \times 10^{8}\right.$ cells $\mathrm{cm}^{-3}$, average cell volume $\left.0.07 \mu \mathrm{m}^{-3}\right)$. The average cell size increased by 30 to $100 \%$ during the growth phase of the bacterial populations in the enrichments with protein, glycine, chitin and glucose. However, changes in BB in the incubations were mainly explained by variation in cell numbers $\left(r^{2}=0.747\right)$ and less by changes in volume of the cells $\left(\mathrm{r}^{2}=0.474\right)$. Concentration of lipid-bound phosphate (PL) was determined as an indicator of cell surface, and total adenylates $\left(\mathrm{ATP}+\mathrm{ADP}+\mathrm{AMP}=A_{T}\right)$ as potentials of metabolic energy. Changes of the total microbial biomass in the sediments, including microeucaryotes, can be detected with both methods. PL concentration was $16 \mathrm{nmol} \mathrm{P} \mathrm{cm} \mathrm{cm}^{-3}$ and $A_{T}$ concentration was equivalent to $0.13 \mu \mathrm{g}$ ATP $\mathrm{cm}^{-3}$ sediment on Day 0 (Fig. 3). The levels of these biomass parameters did not vary by more than $\pm 50 \%$ in the control during $63 \mathrm{~d}$ of incubation. However, the biomass changes in the enrichments with glucose, chitin, glycine and albumin exceeded the background variation in the control significantly. All biomass parameters were significantly correlated with $\mathrm{p}<0.01\left(\mathrm{PL} \times A_{T}, \mathrm{r}^{2}=0.616 ; \mathrm{BB} \times\right.$ $\left.\mathrm{PL}, \mathrm{r}^{2}=0.542 ; \mathrm{BB} \times A_{r}, \mathrm{r}^{2}=0.462 ; \mathrm{n}=64\right)$. For bacterial biomass, a ratio of C:ATP $=1000$ (per weight) was determined at the beginning of the experiment, decreasing to approximately C:ATP $\approx 300$ towards the end. ATP concentrations were approximately $30 \%$ of $A_{T}$. The conversion factor of PL to $C$ biomass of bacteria was equivalent to $200-350 \mu \mathrm{mol} \mathrm{P} \mathrm{g}^{-1} \mathrm{C}$. 
a) day 10

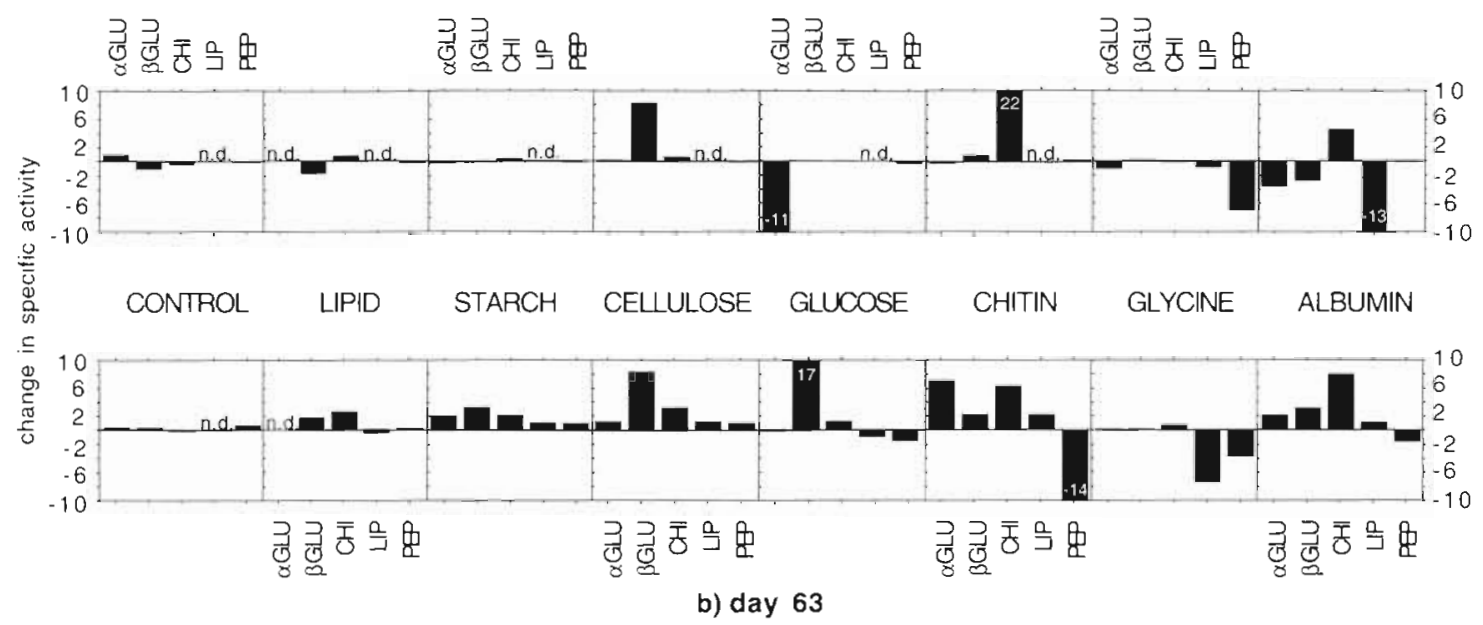

Fig. 2. Enhancement of specific enzymatic activities. Each graph shows the enhancement factors ( $y$-axis) for increase or reduction of specific EEA relative to Day 0 of each enzyme ( $x$-axis) on (a) Day 10, except in the control plot which presents data from Day 5, and (b) Day 63. Columns at the zero level indicate that no change was observed compared to Day 0 . Factors were calculated as $\left(\mathrm{X}_{63 \mathrm{~d}} / \mathrm{X}_{0 \mathrm{~d}}\right)-1$ for positive changes and $1-\left(\mathrm{X}_{0 \mathrm{~d}} / \mathrm{X}_{63 \mathrm{~d}}\right)$ for negative changes, where $\mathrm{X}=$ specific EEA in $\mu \mathrm{mol}^{-1}$ (mg bacterial $\mathrm{C}^{-1}$ n.d.: not detected

Enrichment with pure C compounds

No significant growth was observed after the enrichment with the polymeric lipid, starch or cellulose compared to the 'control' level. In the enrichment with glucose, different patterns were found for changes in $B B, P L$ and $A_{T}$ : a significant increase in $B B$ was observed between Days 10 and 21 (Fig. 3). Between Days 21 and 38, a significant drop in $\mathrm{BB}$ to $60 \mu \mathrm{g} \mathrm{C} \mathrm{cm}^{-3}$ occurred, after which BB increased once more. Only the second increase was reflected in ATP and PL concentrations. Average cell volumes increased from 0.07 to

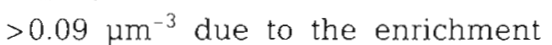
with glucose and cell numbers rose from $22.5 \times 10^{8}$ to $43 \times 10^{8}$ cells $\mathrm{cm}^{-3}$, producing a yield of $100 \mu \mathrm{g} \mathrm{C} \mathrm{cm}^{-3}$ (Table 1). During the growth phase

Fig. 3. Bacterial biomass, lipid-bound phosphate and total adenylates. Scale of the left axis indicates concentrations of lipid-bound phosphate (nmol $\mathrm{cm}^{-3}$ ) and of total adenylates in ATP equivalents $\left(10^{-2} \mu \mathrm{g} \mathrm{cm}^{-3}\right)$. Scale of the right axis indicates concentrations of bacterial biomass ( $\left.\mu \mathrm{g} \mathrm{C} \mathrm{cm}{ }^{-3}\right)$. Error bars indicate $95 \%$ confidence limits of each measurement

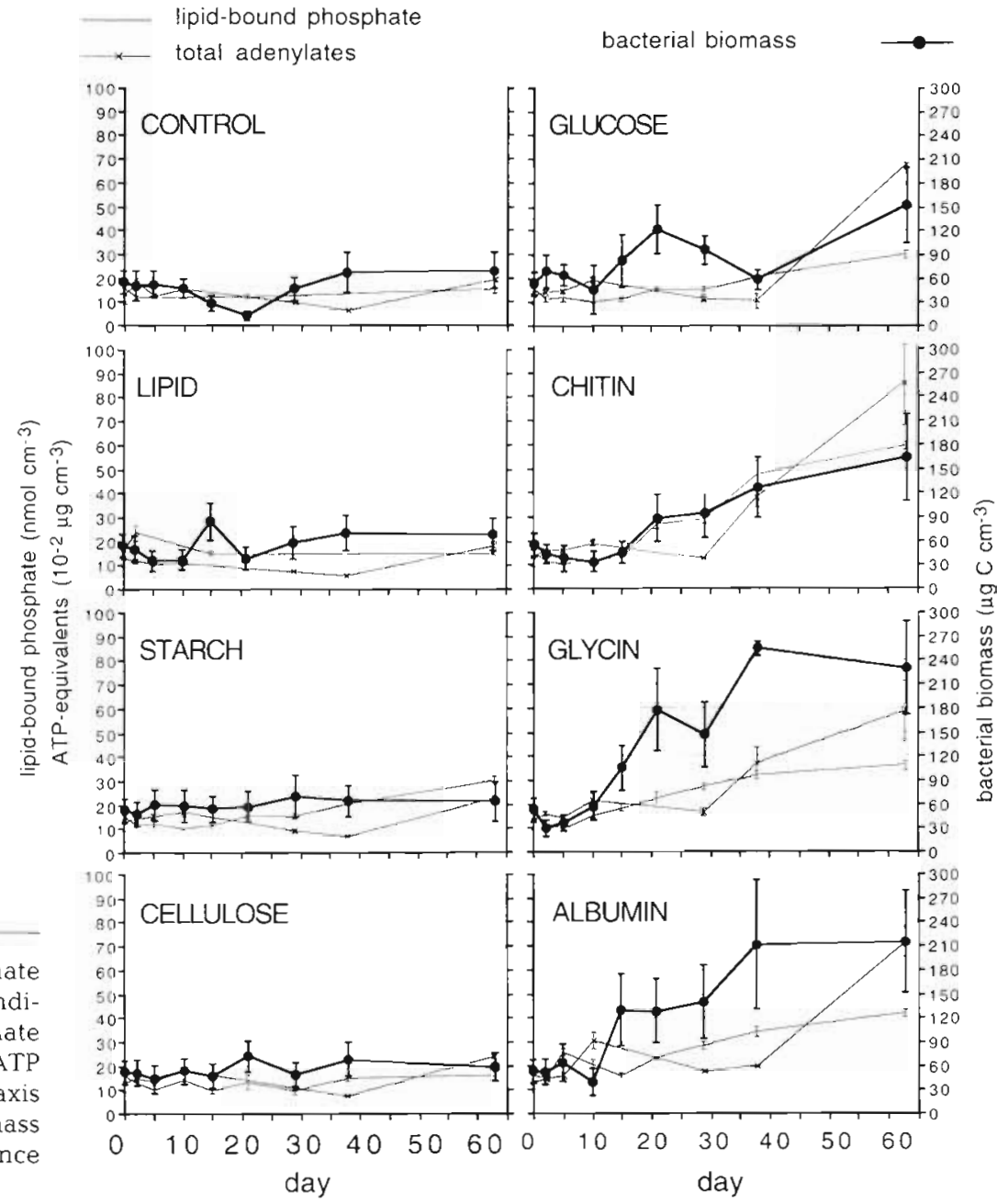


Table 1. Growth parameters and substrate utilization Substrate concentration was normalized to the undiluted sedlment volume. Bacterial $N$ was calculated using a $C / N$ ratio (per weight) of 5.5 (Bratbak 1985). BB: bacterial biomass Yield was calculated as $Y=B B_{6,3 d}-B B_{0 d}$. Substrate conversion was estimated, dividing yield by substrate supply. Growth rates $(\mu)$ were calculated for the interval, Days 10 to 21 with $\mu=\ln \left(\mathrm{BB}_{t_{21}}-\operatorname{InBB}_{t_{10}}\right) /\left(t_{21}-t_{10}\right)$. Doubling times $\left(t_{\mathrm{d}}\right)$ were calculated according to the relation $t_{\mathrm{d}}=\ln 2 / \mu$. Only those sub-

strates are listed which gave rise to bacterial growth

\begin{tabular}{|c|c|c|c|c|}
\hline $\begin{array}{r}\text { Substrate: } \\
\mathrm{C} / \mathrm{N}\end{array}$ & $\begin{array}{l}\text { Glucose } \\
\text { pure C }\end{array}$ & $\begin{array}{c}\text { Chitın } \\
8\end{array}$ & $\begin{array}{c}\text { Albumin } \\
4\end{array}$ & $\begin{array}{c}\text { Glycine } \\
2\end{array}$ \\
\hline $\begin{array}{l}\text { Substrate supply } \\
\left(\mu \mathrm{g} \mathrm{C} \mathrm{cm}^{-3}\right) \\
\left(\mu \mathrm{g} \mathrm{N} \mathrm{cm} \mathrm{cm}^{-3}\right)\end{array}$ & $\begin{array}{r}1350 \\
0\end{array}$ & $\begin{array}{r}1920 \\
280\end{array}$ & $\begin{array}{l}870 \\
250\end{array}$ & $\begin{array}{l}540 \\
300\end{array}$ \\
\hline 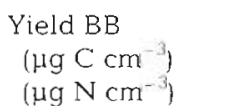 & $\begin{array}{r}100 \\
18\end{array}$ & $\begin{array}{r}110 \\
21\end{array}$ & $\begin{array}{r}162 \\
30\end{array}$ & $\begin{array}{r}177 \\
33\end{array}$ \\
\hline $\begin{array}{l}\% \text { substrate conve } \\
\mathrm{C} \\
\mathrm{N}\end{array}$ & $\frac{\text { rsion into }}{7}$ & $\begin{array}{l}\text { Domass } \\
6 \\
8\end{array}$ & $\begin{array}{r}19 \\
8\end{array}$ & $\begin{array}{l}33 \\
11\end{array}$ \\
\hline Growth rate $\left(\mathrm{d}^{-1}\right)$ & 0.09 & 0.09 & 0.1 & 0.1 \\
\hline Doubling time (d) & 8 & 8 & 7 & 7 \\
\hline
\end{tabular}

between Days 10 and 21, a growth rate of $0.09 \mathrm{~d}^{-1}$ was reached, equivalent to potential doubling times of $8 \mathrm{~d}$. After $63 \mathrm{~d}, 7 \%$ of the total substrate supply was converted into bacterial biomass

\section{Enrichment with $\mathrm{C}+\mathrm{N}$ compounds}

In the chitin enrichment, BB increased significantly from Day 10 on, which was completely reflected in the PL concentrations. $A_{T}$ stayed at a comparatively low level until Day 29 but increased significantly towards the end of the experiment. Maximum average cell volumes

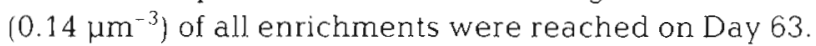

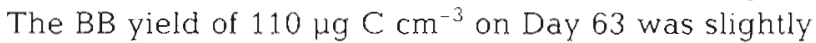
higher than that in the glucose enrichment (Table 1). Between Days 10 and 21, the growth rate of bacterial populations in the chitin enrichment was as high as that obtained with glucose. Of the substrate added to the enrichment, $6 \%$ was converted into $B B$ after $63 \mathrm{~d}$.

In the enrichment with glycine and albumin, $B B$ increased 4 -fold until Day 38. A increased constantly to about 3 times above the control level on Day 63. The rise in PL was delayed until about Day 29, but PL also tripled by Day 63. Average cell volumes increased from 0.07 to $>0.1 \mathrm{~mm}^{-3}$ in both enrichments. Cell numbers rose from 22.5 to $81 \times 10^{8}$ cells $\mathrm{cm}^{-3}$ in the glycine enrichment and to $73 \times 10^{8}$ cells $\mathrm{cm}^{-3}$ in the albumin enrichment. Between Days 10 and 21, growth rates obtained by enrichment with glycine and albumin were similar to those obtained with glucose or chitin, although yields were substantially higher (Table 1). Of glycine and protein carbon, $33 \%$ and $19 \%$, respectively, were converted into biomass after $63 \mathrm{~d}$.

\section{Changes in community structure}

Fatty acids are the main components of microbial cell membranes and, therefore, changes in their composition are indicative of changes in microbial community structure (Bobbie \& White 1980). Twenty-three individual fatty acids were identified in each enrichment at the end of the experiment (Table 2). Fatty acids with broad phylogenetic distribution made up the largest percentage of total fatty acids. Very few substantial changes in the percent contribution of the individual fatty acids were observed. A slightly higher contribution of eucaryotic fatty acids was present in the chitin enrichment, but these were completely absent in the cellulose enrichment. In total, weight percentages of fatty acids of procaryotic or eucaryotic origin did not differ much between treatments. This indicates that none of the treatments was affected by substantial growth of microeucaryotes that are potential bacteriovores. However, the presence of active flagellates and other potential bacteriovores could not be excluded.

\section{DISCUSSION}

Production of extracellular enzymes is one of the most fundamental survival strategies of bacteria in substrate limiting environments (Borriss 1988). However, the synthesis of enzymes which are excreted causes a loss of energy to the cell. Therefore, evolution likely has selected for sophisticated control of extracellular enzyme production and this was confirmed in many studies on various bacteria types. However, in natural assemblages, large numbers of different populations occur in different stages of metabolic activity and, therefore, the 'community' response to substrate supplies of different composition is unpredictable. This shipboard experiment was designed to investigate feed-back mechanisms between supply of certain types of organic molecules and enzyme production as well as growth of a natural microbial assemblage from deep-sea sediments. Sediments were obtained from $1000 \mathrm{~m}$ water depth, presuming that pressure effects due to recovery and handling of the samples at atmospheric pressure are only marginal at this depth (Swartz et al. 1974, Jannasch \& Taylor 1984). Because bacteria from deep-sea sediments generally have long lag phases and low production rates (Deming 1985, Deming \& Colwell 1985. Boetius \& Lochte 1994), a long- 
Table 2. Fatty acid composition in enrichments at the end of the experiment. Data are weight percentages of fatty acids, calculated as (individual fatty acid weight/total fatty acid weight) $\times 100$. Blanks indicate fatty acid concentrations below detection limits. Fatty acids were grouped according to their distribution (Findlay et al. 1990). Lipid enrichment is not included due to analytical problems

\begin{tabular}{|c|c|c|c|c|c|c|c|c|}
\hline Group & Fatty acid & Control & Glycine & Albumin & Chitin & Glucose & Starch & Cellulose \\
\hline \multicolumn{9}{|c|}{ Broad phylogenetic occurence } \\
\hline & $14: 0$ & 7.5 & 4.9 & 5.9 & 11.9 & 7.8 & 13.3 & 8.5 \\
\hline & $16: 0$ & 19.7 & 25.7 & 25 & 17.7 & 2 & 21.6 & 26.1 \\
\hline & $16: 1(n-7)$ & 13.8 & 38.6 & 29.5 & 14.7 & 26.4 & 16.5 & 25 \\
\hline & $18: 0$ & 7.2 & 3.6 & 3.4 & 9.3 & 4 & 5 & 6.6 \\
\hline & $18: 1(n-9)$ & 7.7 & 7.7 & 6.9 & 8.9 & 7.7 & 9.8 & 19.8 \\
\hline Total & & 56 & 81 & 71 & 63 & 48 & 66 & 86 \\
\hline \multicolumn{9}{|c|}{ Prokaryotic } \\
\hline & $15: 0$ & 2.1 & 1.6 & 1.6 & 3.1 & 4.5 & 1.6 & \\
\hline & $16: 1(n-5)$ & 2.7 & 2 & 2.5 & 1.6 & 3.4 & 3.5 & \\
\hline & $17: 0$ & 2.9 & 0.5 & & 0.7 & & & \\
\hline & $18: 1(n-7)$ & 7.4 & 8.1 & 7.6 & 2.9 & 9.4 & 9.5 & 14.2 \\
\hline Total & & 15 & 12 & 12 & 8 & 17 & 15 & 14 \\
\hline \multicolumn{9}{|c|}{ Eukaryotic } \\
\hline & $18: 2(n-6)$ & 2.5 & & 0.8 & 2.7 & & 1.9 & \\
\hline & $18: 3(n-3)$ & & & & 3.5 & & & \\
\hline & $20: 4(n-6)$ & & & & 3.2 & & & \\
\hline & $20: 3$ & 2.8 & 0.9 & 3.7 & 5.2 & 5.8 & 2.9 & \\
\hline & $22: 1(n-9)$ & 3 & & 2.3 & & & & \\
\hline & $22: 5$ & 3 & 1.8 & 2.5 & 1.8 & 3.8 & 3.9 & \\
\hline Total & & 11 & 3 & 9 & 16 & 10 & 9 & 0 \\
\hline
\end{tabular}

term incubation was necessary. But since bacterial production and mortality were not determined in this experiment, conclusions based on our estimates of growth rates and substrate conversion efficiency should be limited to the discussion of treatment effects. Due to the restricted sample size and ship time, the multitude of interactions tested had to be done at the expense of statistical support of the data by replicate treatments. For all these reasons, the results presented mainly show trends, but should stimulate further studies of microbial utilization of different substrates in deep-sea sediments.

\section{Response of hydrolytic EEA to substrate addition}

\section{Negative control mechanisms}

Bacteria produce hydrolytic enzymes at a basal level, which supports the release of products carrying the information' for induction or repression of enzyme synthesis (Priest 1992). Repression of enzyme synthesis at increased concentrations of readily utilizable compounds is a principal regulation mechanism that prevents excess production of the enzymes and, therefore, helps to control the energy expenses of the cell. In our experiment, the addition of glucose and glycine immediately decreased $\alpha$-glucosidase and peptidase EEA, respectively, for over $30 \mathrm{~d}$ (Fig. 1). This effect can be related to $\mathrm{C}$ or $\mathrm{N}$ catabolite repression of the synthesis of enzymes involved in the $\mathrm{C}$ or $\mathrm{N}$ metabolism (Priest 1984).

The addition of chitin greatly suppressed peptidase activity during the $63 \mathrm{~d}$ of incubation (Fig. 2), probably because the uptake of the hydrolysis product $\mathrm{N}$-acetyl-glucosamine satisfies both $C$ and $N$ requirements of the bacteria. Further, the pure $\mathrm{C}$ enrichments like glucose and cellulose seem to have had a negative effect on peptidase activity, as is suggested by the drop in EEA during the first third of the experiment (Fig. 1) compared to the higher peptidase EEA in the control on Day 21. A similar control mechanism regulated protease EEA of 2 strains of marine bacteria and was attributed to both $\mathrm{C}$ and $\mathrm{N}$ catabolite repression (Albertson et al. 1990). The investigations of Jargensen et al. (1993) and Rosenstock \& Simon (1993) showed that marine bacteria utilize a mino acids as additional $C$ sources. Thus, peptidase may well be involved in the $\mathrm{C}$ metabolism of the cells and regulation by $\mathrm{C}$ catabolites could be advantageous. Alternatively, peptidase repression involving pure $C$ compounds could still be connected to the $\mathrm{N}$ metabolism: in situations where enhanced availability of a C source can compensate the energy expense for new synthesis of amino acids from inorganic $N$, it could be beneficial for the cells to stop investing in production of extracellular enzymes. Accordingly, utilization of combined amino acids was reduced with the addition of glucose and $\mathrm{NH}_{4}{ }^{+}$to natural seawater samples (Jørgensen et al. 1993, Middelboe et al. 1995). 


\section{Positive control mechanisms}

Extracellular enzymes are inducible to varying extents, i.e. when catabolic repression is absent, elevated concentrations of specific substrates can enhance the synthesis of certain enzymes, allowing effective and rapid utilization of organic resources. In our experiment, addition of cellulose and chitin induced the production of $\beta$-glucosidase and chitobiase respectively. The EEA of both enzymes increased by an order of magnitude within $10 \mathrm{~d}$. After $38 \mathrm{~d}$, chitobiase EEA exceeded the activity in the control incubation 30-fold. Furthermore, EEA of both glycosidases did not decrease when glucose was added, nor did they increase in the control incubation without additional supply of OM. Therefore, no indication was obtained of a negative control by catabolite repression of both hydrolases. This implies that a rise in the activity of both enzymes is equivalent to an increase in their abundance due to new synthesis of the enzymes.

However, investing in the energy-consuming synthesis and excretion of enzymes is only beneficial if the energy loss is compensated by the gain in readily available products. The calculations of $\mathrm{Y}$. A. Vetter, J. W. Deming \& P. A. Jumars (unpubl.) indicate that secretion of enzymes can only result in an energy gain via uptake of produced hydrolysate when external concentrations of polymeric substrates are very high. The amounts of cellulose and chitin used in our experiment $\left(\sim 1 \mathrm{mg} \mathrm{C} \mathrm{cm}{ }^{-3}\right)$ were certainly higher than they would be naturally in deep-sea sediments; they resemble the level of input into estuarine sediments (Gooday 1990). Nevertheless, the degradation of both compounds is based entirely on microbial communities (Deming \& Baross 1993), and both cellulose and chitin might sporadically occur in high amounts in the deep sea due to large food falls (Rowe \& Staresinic 1979).

\section{Specific EEA and comparison with other aquatic environments}

If the entire bacterial assemblage in a system is considered as a catalyst for the turnover of certain substances, then changes in specific activities of this catalyst characterize its 'effectiveness' in responding to the external availability of substrate. The productive surface layer of the ocean and the sediment surface of the deep-sea floor both contain high amounts of particulate OM, however, of a very different composition. Therefore, the question arises if a general difference in specific EEA of bacteria from different environments can be detected.

In the pelagic surface layer, where starch, glycogen and lipids occur in significant amounts as storage com- pounds of plants and animals, specific activities of $\alpha$ glucosidase and lipase are around 1 to $10 \mathrm{amol} \mathrm{h}^{-1}$ cell $^{-1}$ (Hoppe 1983, Chróst 1991). It was reported that the availability of potential substrates of $\alpha$-glucosidase and lipase induces the production of these enzymes by pelagic bacteria (Somville 1984, Chróst \& Gajewski 1995). However, carbohydrate storage compounds are easily degraded by all heterotrophic organisms and, therefore, largely remineralized in the upper water column (Wakeham \& Lee 1993). This may be the reason why specific activities of $\alpha$-glucosidase and lipase are much lower in oceanic sediments than in the pelagic realm (0.01 to $0.1 \mathrm{amol} \mathrm{h}^{-1}$ cell $^{-1}$; Boetius 1995. Poremba \& Hoppe 1995). Furthermore, the production of these enzymes by benthic bacteria from deep-sea sediments was not inducible by the addition of starch and a lipid in this experiment, nor by a natural mixture of plankton detritus (Boetius \& Lochte 1994).

Structural compounds like cellulose and chitin are less labile and a certain proportion of these substances in settling particles may reach the sea floor. This could be the reason for the high level of the specific activities of $\beta$-glucosidase and chitobiase in deep-sea sediments compared to $\alpha$-glucosidase and lipase. With 1 to $100 \mathrm{amol} \mathrm{h}^{-1}$ cell $^{-1}$ (Boetius 1995, Poremba \& Hoppe 1995), the specific activities of $\beta$-glucosidase and chitobiase are similar to those of pelagic bacteria (Hoppe 1983). However, the regulation of $\beta$-glucosidase observed in surface waters (Chróst et al. 1989. Chróst \& Overbeck 1990, Münster 1991, Middelboe \& Søndergaard 1993) was very similar to peptidase regulation in deep-sea sediments with respect to the inhibitory effect of glucose, amino acid and plankton extract (Boetius \& Lochte 1994). In contrast, $\beta$-glucosidase and chitobiase in this experiment with benthic bacteria were not repressed by addition of glucose, but highly inducible by the addition of their respective substrates or plankton extract (Boetius \& Lochte 1994). Recent investigations on microbial activity in continental slope sediments detected typical variations in specific EEA of bacterial assemblages along trophic gradients: several glycosidases were positively correlated to the input of phytoplankton detritus into slope sediments; however, peptidase activity increased with increasing water depth and decreasing food availability (Vetter \& Deming 1994, Poremba \& Hoppe 1995, Boetius \& Lochte in press, Boetius et al. in press).

Proteinaceous compounds are rapidly remineralized in the upper water column (Smith et al. 1992) and only a small fraction of the amino acid flux reaches deepsea sediments (Wakeham \& Lee 1993). Nevertheless, specific peptidase EEA is extremely high in deep-sea sediments ( 1 to $10 \mathrm{fmol} \mathrm{h}^{-1}$ cell $^{-1}$ ), strongly exceeding that of pelagic bacteria $\left(0.01\right.$ to $0.1 \mathrm{fmol} \mathrm{h}^{-1} \mathrm{cell}^{-1}$; Hoppe 1983, Chróst et al. 1989, Smith et al. 1992, 
Hoppe et al. 1993) and even that of bacteria attached to aggregates (0.5 $\mathrm{fmol} \mathrm{h}^{-1}$ cell $^{-1}$; Smith et al. 1992). Up to now, there has been no explanation for these high activities in deep-sea sediments. The fact that peptidase activity was not specifically induced by the addition of albumin, but suppressed by the addition of glycine, chitin and glucose, suggests a predominant regulation by $\mathrm{C}+\mathrm{N}$ repression. Therefore, high peptidase activity of benthic bacteria may probably be a sign of very oligotrophic conditions.

\section{Response of microbial growth to substrate addition}

\section{Growth rates of benthic bacteria}

In several enrichment experiments with natural assemblages of bacteria in deep-sea sediments from various oceanic regions (2000 to $8000 \mathrm{~m}$ water depth), long lag phases of several days were observed and a range of bacterial growth rates of around 0.1 to $0.5 \mathrm{~d}^{-1}$ were reported (Deming 1985, Deming \& Colwell 1985, Deming \& Baross 1993, Boetius \& Lochte 1994). Similar to these results, the enrichment of bacterial populations in Arctic sediments from $1000 \mathrm{~m}$ water depth with 0.5 to $2 \mathrm{mg} \mathrm{C} \mathrm{cm}^{-3}$ of glycine, albumin, chitin and glucose resulted in growth rates of approximately $0.1 \mathrm{~d}^{-1}$ after a lag phase of around $10 \mathrm{~d}$ (Table 1). Such data indicate that an increase in the bacterial biomass in the sediment might not be detected earlier than 2 wk after a pulse of $O M$ to the sea floor, or not at all, if the material does not include readily available substrates with a low $\mathrm{C} / \mathrm{N}$ ratio. In the NE Atlantic, strong seasonal sedimentation events have been reported, equivalent to an input of 5 to $50 \mu \mathrm{g} \mathrm{C} \mathrm{cm} \mathrm{Cm}^{-3}$ at the sediment surface and containing high amounts of protein (Thiel et al. 1988/89). These fresh phytodetritus deposits during summer in the NE Atlantic were reflected in not more than double the bacterial biomass compared to the spring and autumn situation at the same site, which may have been caused by grazing pressure and competition for food, since a variety of benthic organisms were attracted by this rich food resource (Thiel et al. 1988/89, Lochte 1992)

The natural bacterial assemblage investigated in this experiment originated from 1 batch of freshly sampled, unsieved sediment which was incubated after moderate dilution $(1: 2)$ with filtered seawater overlying the sediments. Therefore, it is likely that grazers were present in the enrichments. However, the high ratio of $\mathrm{PL}$ to $\mathrm{BB}$ of $>200 \mathrm{nmol} \mathrm{P} \mathrm{g}{ }^{-1} \mathrm{C}$ indicated the dominance of bacterial biomass in the sediments (Dobbs \& Findlay 1993). Furthermore, in the enriched sediments, variation in the biomass-related parameters PL and $A_{T}$ were largely explained by changes in bacterial biomass and no indication of microeucaryotic growth was found in the fatty acid signature of the enrichments. Despite these indications of low abundance and low growth of microeucaryotic grazers, this does not totally exclude active grazing. Hence, our calculations of substrate conversion efficiencies in this long-term experiment reflect only those proportions of organic carbon which ended up in bacterial biomass and were not transferred to a higher trophic level of the food web during the $63 \mathrm{~d}$ of incubation.

\section{Effect of substrate composition}

Bacterial biomass in the unenriched sediment did not increase significantly during $63 \mathrm{~d}$ of incubation, suggesting that utilization of sedimentary organic $\mathrm{C}$ did not provide sufficient energy for an increase of the bacterial standing stock. Most strikingly, bacterial populations were also not able to grow on starch or lipid as carbon or energy sources. This was paralleled by the low activities of those hydrolases necessary for degradation and the lack of their induction when the respective substrates were added. Addition of cellulose induced the synthesis of one enzyme specific for its decomposition ( $\beta$-glucosidase), but no significant biomass yield was obtained during the $63 \mathrm{~d}$. The only enrichment with a pure $\mathrm{C}$ source that resulted in significant growth of the bacteria was glucose.

To grow on glucose, bacteria must have sequestered organic or inorganic sedimentary $N$ sources to synthesize amino acids, eventually using part of the $C$ supply as an energy source for 'expensive' pathways such as nitrate assimilation. With the addition of chitin, an important source of both $\mathrm{C}$ and $\mathrm{N}$ was supplied to those microbial organisms with chitinolytic activities (Boyer 1994). However, some of the chitin-C should have been utilized to compensate for the energy loss due to synthesis of the necessary enzymes, in this experiment at least for a 30 -fold increase in chitobiase. Intriguingly, enrichment with chitin resulted in a similar BB yield and substrate conversion as obtained by addition of readily available glucose. Addition of glycine and albumin, both providing a source for amino acids, produced the highest yield in bacterial biomass. These results suggest that the bacterial assemblage in the Arctic sediment was limited by a source of easily accessible $\mathrm{N}$.

\section{Consequences for OM degradation in deep-sea sediments}

The results of our experiment indicate that the composition of deposited OM will strongly influence 


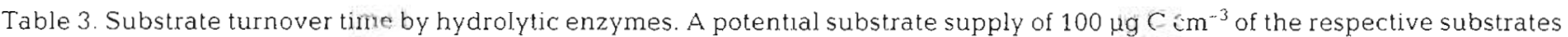
was divided by the average EEA of the substrate-specific enzyme, converted to $\mu \mathrm{g} \mathrm{C} \mathrm{cm}^{-3} \mathrm{~d}^{-1}$. This was calculated according to

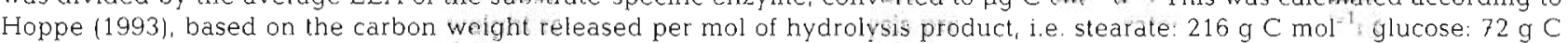
$\mathrm{mol}^{-1}$; $\mathrm{N}$-acetylglucosamine: $96 \mathrm{~g} \mathrm{C} \mathrm{mol}^{-1}$; leucine: $72 \mathrm{~g} \mathrm{C} \mathrm{mol}^{-1}$

\begin{tabular}{|c|c|c|c|c|c|}
\hline $\begin{array}{r}\text { Substrate supply }\left(100 \mu \mathrm{g} \mathrm{C} \mathrm{cm}^{-3}\right) \text { : } \\
\text { Enzyme: }\end{array}$ & $\begin{array}{l}\text { Lipid } \\
\text { Lipase }\end{array}$ & $\begin{array}{c}\text { Starch } \\
\alpha \text {-Glucosidase }\end{array}$ & $\begin{array}{l}\text { Cellulose } \\
\beta \text {-Cilucosidase }\end{array}$ & $\begin{array}{l}\text { Chitin } \\
\text { Chitobiase }\end{array}$ & $\begin{array}{l}\text { Albumin } \\
\text { Peptidase }\end{array}$ \\
\hline Average EEA $\left(\mu \mathrm{g} \mathrm{C} \mathrm{cm}^{-3} \mathrm{~d}^{-1}\right)$ & 5 & 4 & 83 & 461 & 5328 \\
\hline Hydrolysis time (d) & 20 & 25 & 6 & 0.2 & 0.02 \\
\hline
\end{tabular}

hydrolysis rates and, consequently, microbial utilization of different types of $\mathrm{OM}$. Table 3 gives an example of such an effect on the velocity of OM degradation. Since these estimations are based on the potential enzyme activity at substrate saturation and only consider those enzymes detectable by the fluorogenic model substrates, they do not represent in situ turnover rates. However, they allow a comparison of the effectiveness of degradation of certain types of substrates, which may be of particular relevance during intense sedimentation events. Assuming a sedimentation input of $100 \mu \mathrm{g} \mathrm{C} \mathrm{cm}^{-3}$ of the respective substrates, we estimated how fast such a supply could be hydrolyzed by the different enzymes (Table 3 ), if the enzymes hydrolyzed natural and model substrates at a similar velocity. Such an assumed input is of the same order as observed for an intense sedimentation event of natural phytodetritus at an abyssal site in the NE Atlantic (Thiel et al. 1988/89). The most active enzyme was peptidase, present at such high levels that its potential activity would suffice for degradation of a respective protein source within hours. Also chitobiase hydrolytic activity was high enough to rapidly supply readily available products to the bacterial cells within $1 \mathrm{~d}$. In contrast, the low velocities of $\alpha$-glucosidase, lipase and $\beta$-glucosidase in the hydrolysis of their respective substrates result in turnover times of weeks, and, therefore, could represent a rate limiting step for growth of the benthic bacteria. This is in contrast to the pelagic environment, where bacteria sustain much higher specific activities of these enzymes, but lower specific activities of the peptidase compared to deepsea sediments (Hoppe 1983, Chróst 1991).

Furthermore, the availability of different organic substrates led to a considerable variation in bacterial growth yields. The supply with sources of organic N resulted in significant growth of the bacteria. The quickest response in bacterial growth to OM supply was obtained when adding free or combined amino acids resulting in significant multiplication of bacterial cells within $1 \mathrm{wk}$. Thus, $\mathrm{N}$ limitation might be the most important factor controlling bacterial growth in deepsea sediments; however, this was also observed in studies on shallow water benthic environments (Newell 1984, Alongi \& Hanson 1985). Additionally, energy limitation had an effect on the growth performance of the benthic deep-sea bacteria. of the pure $C$ sources supplied to the bacterial assemblage in the sediments, only the high supply of free glucose provided enough energy to the benthic populations to sequester sedimentary $\mathrm{N}$ for growth. This indicates that high inputs of labile organic $\mathrm{C}$ to sediments might favour additional degradation of sedimentary organic compounds, which is similar to the conclusions of Graf (1987). The proportion of labile organic $N$ in settling OM will largely influence the growth efficiency of benthic bacteria, resulting in a higher amount of organic $C$ that is converted into biomass instead of being respired by the benthic bacteria.

Acknowledgements. We thank the scientific party and crew of RV 'Polarstern' cruise ARK IX/4 for support during work at sea, C. Lorenzen for technical assistance in counting bacteria, L. Medlin and 3 anonymous reviewers for thelr very helpful comments on the manuscript. This is publication no. 1100 of the Alfred Wegener. Institute for Polar and Marine Research and publication no. 229 of the Institute for Baltic Sea Research.

\section{LITERATURE CITED}

Albertson NH, Nyström T, Kjelleberg S (1990) Exoprotease activity of two marine bacteria during starvation. Appl Environ Microbiol 56:218-223

Alongi DM, Hanson RB (1985) Effect of detritus supply on trophic relationships within expenmental benthic food webs. II. Microbial responses, tate and composition of decomposing detritus. J Exp Mar Biol Ecol 88:167-182

Arnosti C, Repeta DJ (1994) Oligosaccharide degradation by anaerobic marine bacteria: characterization of an experimental system to study polymer degradation in sediments. Limnol Oceanogr 39:1865-1877

Barnett PRO, Watson J, Conelly D (1984) A multiple corer for taking virtually undisturbed samples trom shelf, bathyal and abyssal sediments. Oceanol Acta 7:399-408

Bobbie RJ, White DC (1980) Characterisation of benthic microbial community structured by high resolution gas chromatography of fatty acid methyl esters. Appl Environ Microbiol 39: 1.212-1222

Boetius A (1995) Microbial hydrolytic enzyme activities in deep-sea sediments. Helgoländer Meeresunters 49 $177-187$ 
Boetius A, Lochte K (1994) Regulation of microbial enzymatic degradation of OM in deep-sea sediments. Mar Ecol Prog Ser 104:299-307

Boetius $A_{1}$ Lochte $K$ (in press) High proteolytic activities of deep-sea bacteria from oligotrophic polar sediments. In: Simon M (ed) Proceedings of the Aquatic Microbial Ecology Workshop in 1995. Arch Hydrobiol

Boetius A, Scheıbe S, Tselepides A, Thiel $H$ (in press) Microbial biomass and activities in deep-sea sediments of the Eastern Mediterranean: trenches are benthic hotspots. Deep Sea Res I

Borriss R (1988) Zelldifferenzierung und Bildung extrazellularer Enzyme. In: Hecker M. Babel W (eds) Physiologie der Mikroorganismen. Gustav-Fischer-Verlag, Jena, $p$ 266-282

Børsheim KY, Bratbak G, Heldal M (1990) Enumeration and biomass estimation of planktonic bacteria and viruses by transmission electron microscopy. Appl Environ Microbiol 56:352-356

Boyer JN (1994) Aerobic and anaerobic degradation and mineralization of ${ }^{14} \mathrm{C}$-chitin by water column and sediment inocula of the York river estuary. Virginia. Appl Environ Microbiol 60:174-179

Bratbak G (1985) Bacterial biovolume and biomass estimation. Appl Environ Microbiol 49:1488-1493

Chróst RJ (1991) Environmental control of the synthesis and activity of aquatic microbial ectoenzymes. In: Chróst RJ (ed) Microbial enzymes in aquatic enviroments. SprungerVerlag, Berlin, p 29-59

Chróst RJ، Gajewko AJ (1995) Microbial utilization of lipids in lake water. FEMS Microbiol Ecol 18:45-50

Chróst RJ, Münster U, Rai H, Albrecht D, Witzel PK, Overbeck J (1989) Photosynthetic production and exoenzymatic degradation of organic matter in the euphotic zone of a eutrophic lake. J Plankton Res 11:223-242

Chrost RJ, Overbeck L (1990) Substrate-ectoenzyme interaction: significance of $\beta$-glucosidase activity for glucose metabolism by aquatic bacteria. Arch Hydrobiol Beih Ergeb Limnol 34:93-98

Deming JW (1985) Bacterial growth in deep-sea sediment trap and boxcore samples. Mar Ecol Prog Ser 25:305-312

Deming JW, Baross JA (1993) The early diagenesis of organic matter: bacterial activity. In: Engel MH, Macko SA (eds) Organic geochemistry: principles and applications. Plenum Press, New York, p 119-144

Deming JW, Colwell R (1985) Observations of barophilic microbial activity in samples of sediments and intercepted particulates from the Demerara Abyssal Plain. Appl Environ Microbiol 50:1002-1006

Dobbs FC. Findlay RH (1993) Quantitative description of microbial communities using lipid analysis. In: Kemp PF (ed) Handbook of methods in aquatic microbial ecology. Lewis Publishers, Boca Raton, FL, p 271-284

Findlay RH, King GM. Watling L (1989) Efficacy of phospholipid analysis in determining microbual biomass in sediments. Appl Environ Microbiol 55:2888-2893

Findlay RH, Trexler MB, Guckert JB, White DC (1990) Laboratory study of disturbance in marine sediments: response of a microbial community. Mar Ecol Prog Ser 62:121-133

Fütterer DK (1994) The expedition Arctic '93 LEG ARK-IX-4 of RV Polarstern 1993. Rep Polar Res 149

Gooday GW (1990) The ecology of chitin degradation. In: Marshall $\mathrm{KC}$ (ed) Advances in microbial ecology 11. Plenum Publishing Corp, New York, p 387-430

Gottschalk G (1986) Bacterial metabolism. Springer-Verlag, New York

Graf G (1987) Benthic energy flow during a simulated autumn bloom sedimentation. Mar Ecol Prog Ser 39:23-29

Greiser N, Faubel A (1988) Biotic factors. In: Higgins RP, Thie] $\mathrm{H}$ (eds) Introduction to the study of meiofauna. Smithsonian Institution Press, Washington, DC, p 79-114

Grossmann S, Reichardt W (1991) Impact of Arenicola marina on bacteria in intertidal sediments. Mar Ecol Prog Ser 77. $85-93$

Hedges JL, Keil RG (1995) Sedimentary organic matter preservation: an assessment and speculative synthesis. Mar Chem 49:81-115

Hoppe HG (1983) Significance of exoenzymatıc activities in the ecology of brackish water: measurements by means of methylumbelliferyl-substrates. Mar Ecol Prog Ser 11: 299-308

Hoppe HG (1993) Use of fluorogenic model substrates for extracellular enzyme activity (EEA) measurement of bacteria. In: Kemp PF (ed) Handbook of methods in aquatic microbial ecology. Lewis Publishers, Boca Raton, FL, p $423-431$

Hoppe HG, Ducklow H, Karrasch B (1993) Evidence for dependency of bacterial growth on enzymatic hydrolysıs of particulate organic matter in the mesopelagic ocean. Mar Ecol Prog Ser 93:277-283

Jahnke RA, Jackson GA (1992) The spatial distribution of sea floor oxygen consumption in the Atlantic and Pacific oceans. In: Rowe GT, Pariente $V$ (eds) Deep-sea food chains and the global carbon cycle. Kluwer Academic Publishers, Dordrecht, p 295-307

Jannasch HW, Taylor CD (1984) Deep-sea microbiology. A Rev Microbiol 38:487-514

Jørgensen NOG, Kroer N, Coffin RB, Yang XH, Lee C (1993) Dissolved free amino acids, combined amino acids, and DNA as sources of carbon and nitrogen to marine bacterla. Mar Ecol Prog Ser 98:135-148

Karl DM (1980) Cellular nucleotide measurements and applications in microblal ecology. Microb Rev 44:739-796

Karl DM, Holm-Hansen $O$ (1978) Methodology and measurement of adenylate energy charge ratios in environmental samples. Mar Biol 48:185-197

Kattner G, Krause $M$ (1987) Changes in lipids during the development of Calanus finnmarchicus. f. l. from Copepodite I to adult. Mar Biol 96:511-518

Kuenen JG, Robertson LA (1993) Interactions among bacteria metabolizing inorganic nitrogen compounds. In: Guerrero R. Pedros-Alió C (eds) Trends in microbial ecology. Spanish Soclety for Microbiology, p 33-36

Lochte K (1992) Bacterial standing stock and consumption of organic carbon in the benthic boundary layer of the abyssal North Atlantic. In: Rowe CT, Pariente V (eds) Deep-sea food chains and the global carbon cycle. Kluwer Academic Publishers, Dordrecht, p 1-10

Meyer-Reil LA (1983) Benthic response to sedimentation events during autumn to spring at a shallow water station in the western Kiel Bight. Mar Biol 77:247-256

Meyer-Reil LA, Köster M (1992) Microbial life in pelagic sediments: the impact of environmental parameters on enzymatic degradation of organic matenal. Mar Ecol Prog Ser $81: 65-72$

Middelboe M, Borch NH, Kirchman DL (1995) Bacterial utilization of dissolved free amino acıds, dissolved combined amino acids and ammonium in the Delaware bay estuary: effects of carbon and nitrogen limitation. Mar Ecol Prog Ser 128:109-120

Middelboe M. Sondergaard M (1993) Bacterioplankton growth yield: seasonal variations and coupling to substrate lability and $\beta$-glucosidase activity. Appl Environ Microbiol 59:3916-3921 
Münster U (1991) Extracellular enzyme activity in eutrophic and polyhumic lakes. In: Chróst RJ (ed) Microbial enzymes in aquatic environments. Springer-Verlag, Berlin, p 96-122

Newell RC (1984) The biological role of detritus in the marine environment. In: Fasham MJR (ed) Flows of energy and materials in marine ecosystems. Plenum. Press, New York. p $317-344$

Poremba K, Hoppe HG (1995) Spatial varlation of benthic microbial production and hydrolytic enzymatic activity down the continental slope of the Celtic Sea. Mar Ecol Prog Ser 118:237-245

Priest FG (1984) Extracellular enzymes. Van Nostrand Reinhold Co Ltd, Wokingham

Priest FG (1992) Synthesis and secretion of extracellular enzymes in bacterna. In: Winkelmann $G$ (ed) Microbial degradation of natural products. VCH Publishers, Weinheim, p 1-26

Rosenstock B, Simon M (1993) Use of dissolved combined and free amino acids by planktonc bacteria in Lake Constance. Limnol Oceanogr 38:1521-1531

Rowe GT, Sibuet M, Deming JW, Khripounoff A, Tietjen J, Macko S, Theroux R (1991) 'Total' sediment biomass and prcliminary estimates of organic carbon residence time in deep-sea benthos. Mar Ecol Prog Ser 79:99-114

Rowe GT, Staresinic N (1979) Sources of organic matter to the deep-sea benthos. Ambio Spec Rep 6:19-23

Smith DC, Simon M, Alldredge AL, Azam F (1992) Intense hydrolytical enzyme activity on marine aggregates and implications for rapid particle dissolution. Nature 359 $139-141$

Somville M (1984) Measurement and study of substrate specificity of exoglucosidase in natural water. Appl Environ Microbiol 48:1181-1185

Stein R (in press) Organic carbon and carbonate distribution in Eurasian Continental Margin and Arctic Ocean decp-

This article was submitted to the editor sea surface sedıments: sources and pathways. In: Stein R, Ivanov $G$, Levitan M, Fahl K (eds) Surface-sediment composition and sedimentary processes in the central Arctic Ocean and along the Eurasian Continental Margin. Rep Polar Res

Swartz RW, Schwarz JR, Landau JV (1974) Comparative effects of pressure on protein and RNA synthesis in bacteria isolated from marine sediments. In: Colwell RR, Morita RA (eds) Effect of the ocean environment on microbial activities. University Park Press, Baltimore, p 145-159

Thiel H, Pfannkuche O, Schriever G, Lochte K, Gooday AJ, Hemleben Ch, Mantoura RFC, Turley CM, Patching JW, Riemann F (1988/1989) Phytodetritus on the deep-sea floor in a central oceanic region of the Northeast Atlantic Biol Oceanogr 6:203-239

Turley CM, Lochte K (1990) Microbial response to the input of fresh detritus to the deep-sea bed. Palaeogeogr Palaeochmatol Palaeoecol (Global and Planetary Change Section) $89: 3-23$

Velji MA, Albright LJ (1986) Microscopic enumeration of marine bacteria of seawater, marine sediment, fecal matter and kelp blade samples following pyrophosphate and ultrasound treatments. Can J Microbiol 32:121-126

Vetter YA, Deming $J$ (1994) Extracellular enzyme activity in the Arctic Northeast Water polynya. Mar Ecol Prog Ser $114: 23-34$

Wakeham SG, Lee C (1993) Production, transport and alteration of particulate organic matter in the marine water column. In: Engel MH, Macko S (eds) Organic geochemistry: principles and applications. Plenum Press, New York, p $145-169$

White DC, Davis WM, Nickels JS, King JD, Bobbie RJ (1979) Determination of the sedimentary microbial biomass by extractable lipid phosphate. Oecologia 40:51-62

Wilkinson L (1989) Statistics. Systat, the system for statistics. Systat Inc, Evanston, l.L

Manuscript first received: March 11, 1996

Revised version accepted: June 25, 1996 